\title{
APLIKASI INTERPRETIVE STRUCTURAL MODELING UNTUK STRATEGI PENGEMBANGAN WAKAF TUNAI DI INDONESIA
}

\author{
Aam Slamet Rusydiana \\ Program Studi Ekonomi Islam, STEI Tazkia \\ Email: aamsmart@gmail.com
}

\section{ARTICLE HISTORY}

Received:

19 September 2018

Accepted:

1 November 2018

Online available:

2 November 2018

\section{Keywords:}

Cash Waqf,

Management,

Interpretive

Structural Modeling, Indonesia Waqf

\begin{abstract}
This research is aim to identify the priority factors that being barrier to develop the practice of cash waqf in Indonesia using Interpretive Structural Modeling (ISM) method. The development of cash waqf in Indonesia with ISM framework is divided into three criteria: (1) Challenges (aspects) faced in developing cash waqf, (2) Strategy or foundation required within the framework of developing cash waqf, and (3) Stakeholders or actors involved in the development of cash waqf in Indonesia. Result show that the core problems and challenges faced in the development of cash waqf institution are: System aspect, product, regulation and information technology. The core strategies or foundations that's needed in framework of cash waqf development are: Transparency and accountability of waqf institutions, Quality development of nadzir, and Innovative marketing strategy from waqf institution. Government and Indonesia Waqf Board are stakeholders or actors involved and related to the development of cash waqf in Indonesia
\end{abstract}

\section{ABSTRAK}

Kata Kunci:

Wakaf Tunai, Manajemen, Interpretive

Structural Modeling, Wakaf Indonesia
Penelitian ini bertujuan untuk mengidentifikasi faktor prioritas yang menjadi penghambat dalam mengembangkan praktik wakaf tunai di Indonesia menggunakan metode Interpretative Structural Modeling (ISM). Pembangunan wakaf tunai di Indonesia melalui framework ISM dibagi menjadi tiga kriteria: (1) Tantangan yang dihadapi dalam pengembangan wakaf tunai, (2) Strategi atau pondasi yang dibutuhkan dalam framework pengembangan wakaf tunai (3) Pemangku kepentingan dan tokoh yang terlibat dalam pembangunan wakaf tunai di Indonesia.Hasil penelitian ini menunjukkan bahwa masalah inti dan tantangan yang dihadapi dalam pembangunan institusi wakaf tunai di antaranya adalah: aspek sistem, produk, regulasi, dan teknologi informasi. Strategi inti atau funasi yang diperlukan dalam framework pembangunan wakaf tunai adalah: Transparansi dan akuntabilitas institusi wakaf, pengembangan kualitas nadzir, dan strategi inovasi pemasaran institusi wakaf. Pemerintah dan Badan Wakaf Indonesia adalah 
pemangku kepentingan atau tokoh yang terlibat dan berhubungan dengan pembangunan wakaf tunai di Indonesia

\section{PENDAHULUAN}

Industri keuangan syariah, menjadi objek studi yang selalu menarik diteliti. Terutama jika dikomparasi dengan kondisi industri keuangan konvensional yang telah lebih dahulu eksis. Misalnya, hasil penelitian yang dilakukan oleh Nurfalah etal (2018) yang menyatakan bahwa perbankan syariah relatif lebih stabil dibandingkan dengan perbankan konvensional dalam menghadapi shock baik dari internal maupun eksternal. Hal ini menjadi temuan menarik yang perlu dibuktikan melalui berbagai riset di masa mendatang.

Selain industri keuangan seperti bank syariah, asuransi syariah, pegadaian syariah dan sebagainya, dalam keuangan Islam dikenal pula entitas keuangan sosial yang juga memiliki peran yang tidak kalah penting. Industri Islamicsocial finance tersebut antara lain adalah lembaga zakat, lembaga wakaf, baitul maal wat tamwiil dan sebagainya. Salah satu instrumen penting dan memiliki potensi yang sangat besar dari sisi sosial maupun finansial adalah wakaf uang.

Wakaf uang merupakan inovasi baru dalam sistem keuangan Islam sektor voluntary disamping zakat, infaq, dan shadaqah. Instrumen ini tidak hanya memecah kebekuan makna institusi wakaf di berbagai negara muslim, tetapi juga merupakan peluang yang luar biasa bagi pengembangan ekonomi sosial umat secara keseluruhan. Wakaf uang juga memberikan kesempatan bagi masyarakat berbagai kalangan untuk berpartisipasi menunaikan wakaf uang sekalipun tidak dalam jumlah besar (Devi, 2015).

Di Indonesia, wakaf uang mulai dikembangkan pada tahun 2001, tatkala para pakar ekonomi Islam melihat banyaknya aset wakaf di Indonesia tidak diberdayakan secara maksimal. Maka pada tahun 2002, Komisi Fatwa Majelis Ulama Indonesia (MUI) mengeluarkan fatwa tentang wakaf uang, yang berisi (1) Wakaf uang (cash waqf/waqf alnuqud) adalah wakaf yang dilakukan seseorang, lembaga atau badan hukum dalam bentuk uang tunai, (2) Termasuk ke dalam pengertian uang adalah surat-surat berharga, (3) Wakaf uang termasuk jawaz (boleh), (4) Wakaf uang hanya boleh disalurkan dan digunakan untuk hal-hal yang dibolehkan syar'i, (5) Nilai pokok wakaf uang harus dijamin kelestariannya, tidak boleh dijual, dihibahkan dan atau diwariskan.

Indonesia sebagai negara mayoritas muslim tentu memiliki potensi wakaf uang yang sangat besar. Menurut Nasution (2012), potensi wakaf uang di Indonesia dengan jumlah umat muslim dermawan diperkirakan sebanyak 20 juta umat dan mewakafkan hartanya dalam bentuk wakaf uang dengan nominal Rp 1 juta per tahun, maka potensi 
wakaf yang terkumpul bisa mencapai Rp 20 Triliun. Disamping itu, menurut Direktorat Pemberdayaan Wakaf Kementerian Agama RI per tanggal Maret 2016 merilis bahwa aset wakaf nasional berupa lahan tanah mencapai 4,35 milyar meter persegi yang tersebar di 435.768 titik wilayah. Dari jumlah tersebut, ada 287.160 lahan yang sudah memiliki sertifikat dan 143.447 lahan yang belum memiliki sertifikat.

Penelitian ini akan mencoba menjawab beberapa pertanyaan penelitian sebagai berikut: Pertama, apa sajakah masalah-masalah yang dihadapi dalam kerangka pengembangan wakaf tunai di Indonesia. Kedua, apa strategi atau dasar pijakan penting dan krusial dalam pengembangan wakaf tunai. Selanjutnya, siapakah sajakah stakeholder yang berperan dalam pengembangan wakaf tunai di Indonesia. Melalui riset dengan metode Interpretive Structural Model (ISM), beberapa pertanyaan tersebut akan coba dijawab.

\section{LANDASAN TEORI}

Pengertian wakaf dalam peristilahan syara', secara umum wakaf adalah sejenis pemberian yang pelaksanaannya dilakukan dengan jalan menahan (pemilikan) asal (tahsibul ashli), lalu menjadikan manfaatnya berlaku umum. Tahsibul ashli adalah menahan barang untuk diwakafkan agar tidak diwariskan, dijual, dihibahkan, digadaikan, disewakan, dan sejenisnya. Cara pemanfaatannya dengan menggunakan sesuai kehendak wakif/tanpa imbalan (Al-Arif, 2010).

Adapun pengertian wakaf menurut UU No. 41 Tahun 2004 Tentang Wakaf Pasal 1 ayat (1) : Wakaf adalah perbuatan hukum wakif untuk memisahkan dan/atau menyerahkan sebagian harta benda miliknya untuk dimanfaatkan selamanya atau untuk jangka waktu tertentu sesuai dengan kepentingannya guna keperluan ibadah dan/atau kesejahteraan umum menurut syariah.

Majelis Ulama Indonesia (MUI) telah mendefinisikan wakaf uang dalam fatwanya tentang kebolehan wakaf pada 11 Mei 2002 yang menyatakan bahwa wakaf uang (cash waqf/waqf al nuqud) adalah wakaf yang dilakukan seseorang, kelompok orang, lembaga atau badan hukum dalam bentuk uang tunai, termasuk dalam pengertian ini adalah suratsurat berharga. Definisi ini kemudian diperkuat dengan lahirnya UU No. 41 Tahun 2004 dan PP No, 42 Tahun 2006 tentang wakaf yang menyatakan bahwa uang termasuk bagian dari benda wakaf.Dapat disimpulkan bahwa wakaf uang adalah aset berupa uang yang dimanfaatkan secara produktif pada sektor halal guna kemaslahatan umat Islam, khususnya mauquf 'alaih. Adapun zat pada wakaf uang tersebut tidak boleh berkurang atau hilang.

Menurut Mu'alim (2014) dalam Haura, Baga, Tanjung (2016), terdapat beberapa ulama yang memperbolehkan wakaf uang, diantaranya :

1. Imam al-Zuhri (w. $124 \mathrm{H}$ ) menjelaskan bahwa mewakafkan dinar hukumnya boleh, dengan cara menjadikan dinar tersebut sebagai modal usaha kemudian keuntungannya disalurkan pada mauquf 'alaih. 
2. Para ulama mutaqaddimin (klasik) dari kalangan madzhab Hanafi, membolehkan wakaf dinar dan dirham sebagai pengecualian, atas dasar Isthsan bi al-'Urf, berdasarkan atsar dari Abdullah bin Mas'ud r.a. "Apa yang dipandand baik oleh kaum muslimin maka dalam pandangan Allah adalah baik, dan apa yang dipandang buruk oleh kamu muslimin maka dalam pandangan Allah pun buruk".

3. Sebagian ulama madzhab al-Syafi'i. "Abu Tsaur meriwayatkan dari Iman al-Syafi'i tentang kebolehan wakaf dinar dan dirham (uang)".

Mas'udi et al. (2016) melakukan analisis terhadap pengembangan wakaf tunai (Waqf al-Nuqud) di Indonesia. Penelitian menunjukan bahwa upaya pengembangan wakaf uang di Indonesia relatif masih baru jika dibandingkan dengan negara lain. Untuk itu diperlukan sinergi antara lembaga nazhir wakaf dengan lembaga amil zakat agar aktivitas wakaf uang lebih cepat berkembang, khususnya pada masa-masa awal pertumbuhannya. Diperlukan peran yang lebih besar dari Lembaga Keuangan Syariah Penerima Wakaf Uang agar sinergi antara nazhir wakaf dengan LKS PWU profesional lebih maksimal.

Haura Arie et al. (2016) melakukan analisis pengelolaan wakaf uang pada Koperasi Jasa Keuangan Syariah (pendekatan Analytical Network Process). Hasil penelitian ini memaparkan proses Koperasi Jasa Keuangan Syariah (KJKS) sebagai nazhir wakaf uang, menganalisa prioritas faktor internal dan eksternal terkait. Prioritas faktor-faktor strategis dalam pengelolaan wakaf uang secara berurutan dari sisi internal adalah Akuntabilitas, Produk, dan SDM KJKS. Dari sisi eksternal adalah Regulasi, Masyarakat Umum, dan Demografi. Secara detail, prioritas utama adalah pada elemen Jumlah Asset dan Pedoman Prinsip Syariah.

Nizar (2014) menganalisis faktor-faktor yang mempengaruhi persepsi wakif tentang wakaf uang menggunakan metode regresi logistik. Hasil analisis data menunjukan bahwa variabel pendidikan memiliki peluang yang lebih besar dan signifikan dalam menjelaskan persepsi wakif tentang wakaf uang. Hal ini karena tingkat pendidikan lebih tinggi mampu mengolah informasi yang diterima secara lebih baik dibandingkan tingkat pendidikan yang lebih rendah sehingga membentuk pemahaman yang lebih baik.

Budiman (2011) mengungkapkan beberapa penyebab yang membuat wakaf tidak efektif. Di salah satu sisi, penyebabnya terkait dengan sumber daya manusia, khususnya pada sisi pengelola (nazhir), penyebab yang lain adalah lemahnya akuntabilitas dari institusi wakaf. Dengan menggunakan pendekatan doktrinal dan non-doktrinal penelitian ini menunjukkan bahwa di PKPU pengelola menerapkan prinsip transparansi dan akuntabilitas dalam mengelola wakaf di dalam lembaga itu. Prinsip akuntabilitas diimplementasikan dalam bentuk audit, baik internal maupun eksternal oleh akuntan publik. Penerapan prinsip akuntabilitas telah meningkatkan kepercayaan publik terhadap lembaga wakaf.

Furqon (2011) mengkaji praktek perwakafan uang pada lembaga keuangan syariah. (Bank Syariah Mandiri). Ada beberapa kesimpulan yang dapat ditarik dari kajian ini antara 
lain : penyebaran informasi wakaf uang masih relatif terbatas dibandingkan dengan kekayaan media dan pengalaman yang dimiliki oleh bank. Untuk meningkakan pemberdayaan wakaf uang tunai ada beberapa rekomendasi yang perlu dilakukan, yaitu Sosialisasi wakaf uang menjadi kewajiban semua pihak. Pemerintah harus memberikan perhatian yang besar terhadap sosialisasi wakaf uang dengan mengalokasikan anggaran yang cukup untuk sosialisasi dan penggalangan wakaf uang. Pihak bank perlu lebih mengintensifkan sosialisasi wakaf uang dengan memanfaatkan layanan promosi produk yang dimilikinya; BWI perlu menyiapkan standar nazhir wakaf uang profesional dan memberikan pelatihan-pelatihan nazhir wakaf professional sehingga wakaf uang dapat berjalan sesuai dengan ketentuan.

Hasbullah (2012) melakukan penelitian mengenai Dinamika Pengelolaan Wakaf Uang dengan melakukan Studi tentang Perilaku Pengelolaan Wakaf Uang Pasca Pemberlakuan UU No. 41 Tahun 2004 tentang Wakaf. Hasil penelitian menunjukan bahwa regulasi wakaf uang kurang mendukung terwujudnya wakaf uang sebagai alat pemberdayaan dan kesejajaran ekonomi di masyarakat. Skema pengelolaaan wakaf uang perlu disempurnakan dengan menjadikan LKS sebagai nazhir dan menjadikan dana wakaf uang sebagai modal bisnis sosial integratif. Wakaf tunai untuk pembangunan sarana ekonomi produktif dan sosial yang berkembang di masyarakat perlu diakomodasi sebagai model wakaf dengan nazhir selain LKS.

Penelitian lain terkait wakaf dan wakaf tunai telah dilakukan oleh Alias etal (2015), Harun et.al (2016), Aziz et.al (2014) Rusydiana \& Devi (2018), Rusydiana \& Devi (2017) danPitchay et.al (2014). Riset yang dilakukan oleh Rusydiana dan Alparisi (2016) menunjukkan bahwa riset-riset wakaf masih didominasi oleh diskusi terkait non-wakaf tunai $(62 \%)$ dibanding riset tentang wakaf tunai (38\%). Hal ini memberikan pandangan umum bagi para peneliti untuk memproduksi riset yang lebih baik terkait wakaf tunai. Sebagai tambahan, perbandingan riset wakaf dengan metode kuantitatif masih lebih sedikit dibandingkan dengan riset dengan pendekatan kualitatif.

\section{METODE PENELITIAN}

\section{Gambaran Umum Metode Interpretative Structural Modelling}

Interpretative Structural Modeling (ISM) merupakan teknik pemodelan yang dikembangkan untuk perencanaan kebijakan strategi (Marimin, 2004). ISM diciptakan pertama kali oleh J. Warfield pada tahun 1973, dimana Warfield mendefinisikan ISM sebagai proses belajar dengan bantuan komputer yang memungkinkan individu-individu atau kelompok untuk mengembangkan peta hubungan yang kompleks antara berbagai elemen yang terlibat dalam situasi yang kompleks (Warfield, 1974). ISM adalah sebuah metodologi perencanaan yang canggih yang digunakan untuk mengidentifikasi dan menyimpulkan aneka macam hubungan antarfaktor dalam sebuah permasalahan atau isu tertentu (Sage, 1977). 
Interpretive Structural Modelling (ISM) sebagaimana diaplikasikan oleh Bhattacharya dan Momaya (2009), adalah metodologi perencanaan interaktif canggih yang memungkinkan sekelompok orang, bekerja sebagai tim, untuk mengembangkan struktur yang mendefinisikan hubungan di antara unsur-unsur dalam suatu himpunan. Struktur diperoleh dengan menjawab pertanyaan sederhana. Unsur yang akan terstruktur (seperti tujuan, hambatan, masalah, dan sebagainya) yang ditentukan oleh kelompok pada awal sesi perencanaan ISM. Proses ISM dimulai dari permodelan system dan diakhiri dengan validasi model. Melalui teknik ISM, model mental yang tidak jelas ditransformasikan menjadi model system yang tampak (visible).

ISM merupakan metode dalam pengambilan keputusan dari situasi yang kompleks dengan menghubungkan dan mengorganisasi ide dalam peta map visual. ISM adalah pemodelan yang menggambarkan hubungan spesifik antarvariabel, struktur menyeluruh dan memiliki output berupa model grafis berupa kuadran dan level variabel (Li \& Yang, 2014). Dalam hal pengambilan keputusan, ISM ada sedikit kesamaan dengan metode Analytic Network Process (ANP) yang dikembangkan Thomas L. Saaty. Misal, penelitian yang dilakukan oleh Rusydiana \& Devi (2013b). Ide dasarnya adalah menggunakan ahli yang berpengalaman dan pengetahuan praktis untuk menguraikan sistem yang rumit menjadi beberapa sub-sistem (elemen) dan membangun sebuah model struktural bertingkat. ISM sering digunakan untuk memberikan pemahaman dasar situasi yang kompleks, serta menyusun tindakan untuk memecahkan masalah (Gorvett and Liu, 2007). Metode ISM banyak diaplikasikan dalam riset manajemen strategis pada berbagai bidang. Dalam riset ekonomi keuangan, Devi dan Rusydiana (2016) mencoba meneliti terkait strategi pengembangan model pinjaman berbasis kelompok di Indonesia.

Dalam pelaksanaan metode ISM terlebih dahulu dilakukan diskusi dengan para pakar (brainstorming) untuk menjaring ide-ide pengembangan organisasi yang terdiri dari orang-orang yang memahami konsep ISM, mengerti masalah pengembangan model pengembangan koperasi syariah, memiliki keahlian di bidang microfinance dan empowerment. Dari diskusi mengenai strategi pengembangan tersebut diperoleh beberapa ide atau variabel yang akan diolah menggunakan ISM.

Langkah pertama dalam pengolahan ISM adalah membuat StructuralSelf Interaction Matrix (SSIM), di mana variabel-variabel tersebut dibuat hubungan konstektualnya dengan menjadikan satu variabel $i$ dan variabel $j$. Selanjutnya adalah membuat reachibility matrix (RM) dengan mengubah $\mathrm{V}, \mathrm{A}, \mathrm{X}$ dan $\mathrm{O}$ dengan bilangan 1 dan 0. Langkah terakhir adalah membuat Canonical Matrix untuk menentukan level melalui iterasi. Setelah tidak ada lagi irisan (intersection), selanjutnya dibuat model yang dihasilkan oleh ISM yang merupakan suatu model untuk memecahkan masalah, dalam hal ini pengembangan model wakaf tunai. Dari model tersebut kemudian nantinya akan dibuat suatu road map pengembangan lembaga (level). 


\section{Hubungan Antarelemen dalam ISM}

Menurut Marimin (2004) proses metode ISM adalah dilakukan perhitungan menurut Aturan Transivity dimana dilakukan koreksi terhadap SSIM sampai terjadi matriks yang tertutup. Modifikasi SSIM membutuhkan masukan dari para panelis/pakar, dengan diberi catatan khusus agar perhatian ditunjukan hanya pada sub-elemen tertentu. Hasil revisi SSIM dan matriks yang memenuhi syarat Aturan Transivity diperoses lebih lanjut. Untuk revisi dapat juga dilakukan transformasi matriks dengan program komputer.

Aturan Transivity merupakan aturan kelengkapan dari lingkaran sebab akibat (casual-loop), sebagai misal :
A mempengaruhi $B$
B mempengaruhi $\mathrm{C}$

Maka A (seharusnya) mempengaruhi C

D meningkatkan E

E meningkatkan $\mathrm{F}$

Maka D (tidak seharusnya) memperkecil $\mathrm{F}$.

Tabel 3.1 Keterkaitan Antar Sub-elemen pada Teknik ISM

\begin{tabular}{|c|c|c|}
\hline No. & Jenis & Interprestasi \\
\hline 1. & Pembandingan (Coperative) & . A lebih penting/besar/indah, daripada B \\
\hline 2. & Peryataan (Definitive) & $\begin{array}{l}\text { A adalah atribut } B \\
\text { A termasuk didalam B } \\
\text { A mengartikan B }\end{array}$ \\
\hline 3. & Pengaruh (Influence) & $\begin{array}{l}\text { A menyebabkan B } \\
\text { A adalah debagia penyebab B } \\
\text { A mengembangkan B } \\
\text {. A menggerakan B } \\
\text {. A meningkatkan B }\end{array}$ \\
\hline 4. & Ruang (Spiral) & $\begin{array}{l}\text { A adalah selatan/ utara B } \\
\text { A diatas B } \\
\text {. A sebelah kiri B }\end{array}$ \\
\hline 5. & Waktu (Temporate/Time Scale) & $\begin{array}{l}\text { A mendahului } B \\
\text { A mengikuti } B \\
\text {. A mempunyai prioritas lebih dari B }\end{array}$ \\
\hline
\end{tabular}

Pengolahan lebih lanjut dari Reachability Matrix yang telah memenuhi Aturan Transivity adalah penetapan pilihan jenjang (level partition). Pengolahan bersifat tabulatif dengan pengisisan format, dan bisa dibantu dengan komputer. Berdasarkan pilihan jenjang maka dapatlah digambarkan skema setiap elemen menurut jenjang vertikal maupun horisontal. 
Untuk beragam sub-elemen dalam suatu elemen berdasar RM disusunlah DriverPower-Dependence. Klasifikasi sub-elemen dipaparkan dalam 4 sektor berikut (Marimin, 2004):

Sektor 1 : Weakdriver-weak dependent variables (AUTONOMOUS). Perubahan disektor ini umumnya tidak berkaitan dengan sistem, dan mungkin memeiliki hubungan kecil, meskipun hubungan bisa saja kuat.

Sektor 2 : Weak driver-strongly dependent variables (DEPENDENT). Umumnya perubahan disisni tidak bebas.

Sektor 3 : Strong driver-strongly dependent variables (LINKAGE). Peubah pada sektor ini harus dikaji secara hati-hati sebab hubungan antar peubah adalah tidak stabil. Setiap tindakan pada peubah tersebuat akan memeberikan dapak terhadap lainnya dan umpan balik pengaruhnya bisa memperbesar dampak.

Sektor 4 : Strong drive weak dependent variables (INDEPENDENT). Peubah pada sektor ini merupakan bagian sisa dari sistem dan disebut peubah bebas.

\section{HASIL DAN PEMBAHASAN}

Berdasarkan identifikasi masalah, strategi, dan hal-hal yang berkaitan dengan pengembangan wakaf tunai di Indonesia, kemudian dibangunlah model kerangka ISM untuk beberapa tujuan yang diinginkan, dalam hal ini terkait aspek masalah atau tantangan yang dihadapi, strategi pengembangan dan stakeholder yang berkepentingan dalam pengembangan wakaf tunai di Indonesia. Untuk membangun hubungan kontekstual antarvariabel dalam model, metode ISM menggunakan opini dari para pakar dengan kerangka VAXO. Kaitannya dengan penelitian ini, sekelompok grup pakar dilibatkan dalam menyusun model yang terdiri dari akademisi dan praktisi wakaf tunai.

Untuk membangun sebuah model, peneliti memutuskan untuk mengikuti metode tradisional yang lazim digunakan melalui brainstorming berikut wawancara mendalam atau indepth interview dengan para pakar dimaksud, untuk kemudian menerima masukan dan merevisi model secara berkala. Beberapa literatur dan studi terkait pengembangan wakaf tunai juga didiskusikan dengan para pakar untuk memvalidasi dan membuat sempurna model.

Untuk menganalisis hubungan antarvariabel atau antar enabler dari pengembangan wakaf tunai dari masing-masing kelompok tujuan, hubungan kontekstual dipilih dengan mendefinisikanbagaimana pengaruh satu variabel terhadap variabel lain: apakah mempengaruhi, dipengaruhi, saling mempengaruhi atau tidak ada hubungan sama sekali. Dari dasar ini, hubungan konstekstual antarvariabel dibangun. Para pakar kemudian ditanya dan diminta justifikasi dalam format kuesioner untuk membandingkan pernyataan dalam kolom dengan baris untuk masing-masing kotak pertanyaan dengan memilih nilai antara $\mathrm{V}, \mathrm{A}, \mathrm{X}$ atau $\mathrm{O}$, untuk merepresentasikan persepsi mereka atas hubungan antara variabel tersebut. 


\section{Structural Self-Interaction Matrix (SSIM)}

Tampak dalam tabel di bawah, terdapat tujuh variabel terkait strategi pengembangan wakaf tunai di Indonesia yang disusun dalam format baris dan kolom. Variabel dalam baris dan kolom direpresentasikan masing-masing dengan huruf i dan j. Dengan demikian, setiap pasangan variabel dianalisis secara terpisah setelah pembentukan grid, yang diperoleh dalam proses di atas. Empat kata kunci digunakan untuk mewakili arah hubungan antara satu set variabel (i dan j), dimana:

(a) $\mathrm{V}$ mengindikasikan bahwa variabel i mempengaruhi variabel $\mathrm{j}$;

(b) A mengindikasikan bahwa variabel j mempengaruhi variabel i;

(c) $\mathrm{X}$ mengindikasikan bahwa variabel i mempengaruhi variabel $\mathrm{j}$ dan sebaliknya variabel $j$ mempengaruhi variabel $i$, atau dengan arti lain terdapat hubungan saling mempengaruhi antara variabel $\mathrm{i}$ dan $\mathrm{j}$;

(d) O mengindikasikan bahwa variabel i dan j tidak saling berhubungan.

Hubungan antarvariabel dalam model direpresentasikan dalam sebuah matriks yang disebut sebagai structural self interaction matrix (SSIM), dengan nilai untuk setiap pasangan variabel menjadi nilai yang disepakati di antara para pakar.

Tabel 4.1. Structural Self Interaction Matrix (SSIM)

\begin{tabular}{lllllllll}
\hline No & \multicolumn{1}{c}{ Deskripsi Variabel } & $\mathbf{7}$ & $\mathbf{6}$ & $\mathbf{5}$ & $\mathbf{4}$ & $\mathbf{3}$ & $\mathbf{2}$ & $\mathbf{1}$ \\
\hline A1 & Transparansi \& akuntabilitas lembaga wakaf & V & A & X & O & V & A & \\
\hline A2 & Peningkatan kualitas nazhir/pengelola & A & V & A & V & O & & \\
\hline A3 & Strategi pemasaran inovatif lembaga wakaf & V & X & X & O & & & \\
\hline A4 & Pengembangan institusi pendidikan wakaf & X & A & X & & & & \\
\hline A5 & Dukungan hukum terkait wakaf & X & V & & & & & \\
\hline A6 & Data yang update dan valid terkait wakaf & A & & & & & & \\
\hline A7 & Teknologi dalam manajemen wakaf tunai & & & & & & \\
\hline
\end{tabular}

Catatan: Entri dalam tabel: $V$ ketika baris mempengaruhi kolom; A ketika kolom mempengaruhi baris; $X$ ketika baris dan kolom saling mempengaruhi; dan $O$ ketika tidak ada hubungan antara baris dan kolom.

\section{Reachibility Matrix}

Reachibility matrix diperoleh dari structural self interaction matrix (SSIM) dengan menggunakan proses dua langkah. Pada langkah pertama, abjad yang digunakan untuk menunjukkan hubungan antarvariabel dalam SSIM diganti dengan " 0 " atau " 1 ". Nilai dalam reachibility matrix tergantung pada jenis hubungan dalam SSIM (Faisal, 2015) dan dirangkum dalam hubungan berikut ini:

(1) Jika hubungan antara variabel dalam satu baris dengan variabel lain dalam kolom adalah "V", maka dalam matriks reachibility awal, entri baris menjadi "1" sementara entri kolom antara dua variabel ini menjadi " 0 "; 
(2) Jika hubungan antara variabel dalam satu baris dengan variabel lain dalam kolom adalah "A", maka dalam matriks reachibility awal, entri baris menjadi "0" sementara entri kolom antara dua variabel ini menjadi "1";

(3) Jika hubungan antara variabel dalam satu baris dengan variabel lain dalam kolom adalah "X", maka dalam matriks reachibility awal, entri baris menjadi "1" sementara entri kolom antara dua variabel ini menjadi "1";

(4) Jika hubungan antara variabel dalam satu baris dengan variabel lain dalam kolom adalah "O", maka dalam matriks reachibility awal, entri baris menjadi "0" sementara entri kolom antara dua variabel ini menjadi " 0 ".

Berdasarkan aturan di atas, matriks reachibility awal untuk enabler strategi pengembangan wakaf tunai dibangun. Selanjutnya, dengan memasukkan konsep transitivitas (Ravi, 2015), matriks reachibility akhir diperoleh. Transitivitas dalam hubungan kontekstual adalah asumsi dasar yang dibuat dalam ISM. Konsep ini menyatakan bahwa jika variabel $X$ terkait dengan $Y$ dan $Y$ terkait dengan $Z$, maka $X$ harus terkait dengan $Z$ (Venkatesh et.al, 2015; Jabeen et.al, 2017). Matriks reachibility juga menyediakan 'driving power' (kekuatan mempengaruhi) dan 'dependence power' dari setiap enabler. Dengan demikian, dalam tabel matriks reachibility terakhir, driving power untuk A1 (Transparansi \& akuntabilitas lembaga wakaf) adalah jumlah total nilai-nilai entri dalam baris, yaitu 7. Sementara itu, nilai 'dependence power' untuk A1 (jumlah dari entri dalam kolom) adalah 4. Demikian pula, nilai-nilai 'driving power' dan 'dependence power' dihitung untuk semua enablers yang tersisa.

Tabel 4.2. Final Reachibility Matrix (RM)

\begin{tabular}{lllllllllc}
\hline No & \multicolumn{1}{c}{ Deskripsi Variabel } & $\mathbf{1}$ & $\mathbf{2}$ & $\mathbf{3}$ & $\mathbf{4}$ & $\mathbf{5}$ & $\mathbf{6}$ & $\mathbf{7}$ & $\begin{array}{c}\text { Driving } \\
\text { power }\end{array}$ \\
\hline A1 & Transparansi\&akuntabilitas lembaga wakaf & 1 & 1 & 1 & 1 & 1 & 1 & 1 & 7 \\
\hline A2 & Peningkatan kualitas nazhir/pengelola & 1 & 1 & 1 & 1 & 1 & 1 & 1 & 7 \\
\hline A3 & Strategi pemasaran inovatif lembaga wakaf & 1 & 1 & 1 & 1 & 1 & 1 & 1 & 7 \\
\hline A4 & Pengembangan institusi pendidikan wakaf & 0 & 0 & 0 & 1 & 0 & 1 & 0 & 2 \\
\hline A5 & Dukungan hukum terkait wakaf & 1 & 1 & 1 & 1 & 1 & 1 & 1 & 7 \\
\hline A6 & Data yang update dan valid terkait wakaf & 0 & 0 & 0 & 0 & 0 & 1 & 0 & 1 \\
\hline A7 & Teknologi dalam manajemen wakaf tunai & 0 & 0 & 0 & 0 & 0 & 1 & 1 & 2 \\
\hline & Dependence Power & 4 & 4 & 4 & 5 & 4 & 7 & 5 & \\
\hline
\end{tabular}

Dari matriks reachibility akhir, langkah selanjutnya adalah membangun 'reachibility set' dan 'antecedent set'. Jangkauan yang ditetapkan untuk enabler tertentu terdiri dari enabler itu sendiri dan enabler lain yang dapat membantu mencapainya. Demikian pula, set anteseden terdiri dari enabler itu sendiri dan enabler lain yang mempengaruhinya. Perpotongan set ini diturunkan untuk semua enablers. Enabler yang mana set persimpangan dan reachibility adalah sama, membentuk level teratas dari hirarki dalam model ISM. Enabler ini tidak akan membantu mencapai enabler lain di atas tingkat 
mereka (Jabeen dan Faisal, 2018). Tingkat yang diidentifikasi membantu dalam membangun kuadran dan model akhir ISM.

\section{Analisis Kuadran MICMAC}

Dalam penelitiannya, Godet (1986) telah mempopulerkan matriks perkalian dampak silang atau 'matrix of cross impact multiplications applied to classification' (MICMAC) untuk mengklasifikasikan variabel sistem yang diteliti. Dasar dari klasifikasi ini adalah 'driving power' dan 'dependence power' yang dihitung dalam matriks reachibility akhir. Selain itu, analisis MICMAC dapat digunakan untuk memeriksa hubungan langsung dan laten di antara enabler yang diperoleh dari teknik ISM. Jadi, berdasarkan 'driving power' dan 'dependence power', enabler dalam penelitian ini diklasifikasikan ke dalam empat kelompok, seperti yang ditunjukkan dan dijelaskan berikut ini:

(1) Variabel Autonomous: Variabel-variabel ini tidak memiliki daya pengaruh yang tinggi atau ketergantungan yang tinggi. Mereka terlepas dari sistem, dimana mereka memiliki beberapa tautan yang mungkin sangat kuat. Kuadran I mewakili variabel otonom (autonomous). Dalam penelitian ini, strategi pemasaran inovatif lembaga wakaftermasuk dalam kategori ini.

(2) Variabel Dependent: Kuadran II merupakan variabel dependen yang memiliki kekuatan mempengaruhi rendah dan ketergantungan tinggi. Dari analisis MICMAC, enabler 1 dan 2 adalah variabel dependen.

(3) Variabel Linkage: Variabel-variabel ini memiliki daya pengaruh yang tinggi sekaligus ketergantungan yang tinggi pula. Karakteristiknya adalah bahwa setiap tindakan pada mereka akan memiliki efek pada variabel di atas tingkat mereka dan efek umpan balik pada diri mereka sendiri. Kuadran III merupakan variabel linkage. Dalam penelitian ini, enabler 5, 6 dan 7 termasuk dalam kategori variabel linkage. Dukungan hukum, data update dan teknologi informasi termasuk dalam variabel linkage ini.

(4) Variabel Independent: Variabel-variabel ini memiliki daya mempengaruhi yang tinggi dan ketergantungan yang rendah. Mereka mewakili Kuadran IV. Dalam penelitian ini, enabler 4 yaitu pengembangan institusi pendidikan wakaf, termasuk dalam kategori ini. 


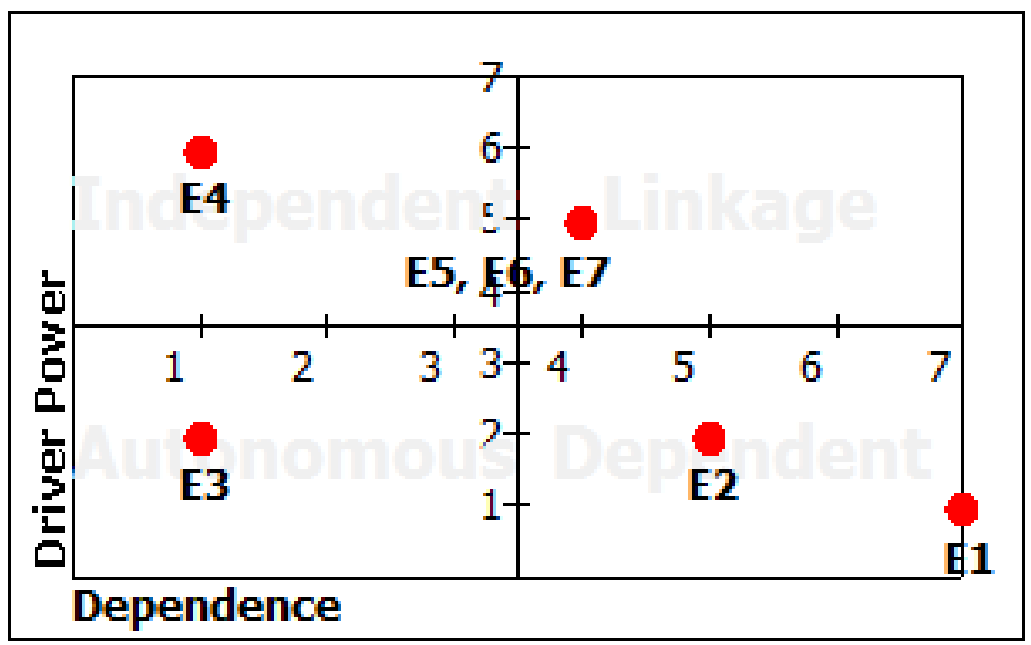

Gambar. 4.1. Analisis MICMAC Strategi Wakaf Tunai

\section{Diskusi}

Dari aspek strategi yang diperlukan dalam kerangka pengembangan wakaf tunai di Indonesia, strategi utama adalah: (a) transparansi dan akuntabilitas lembaga wakaf, (b) peningkatan kualitas nazhir pengelola wakaf tunai, (c) strategi pemasaran yang inovatif dari lembaga wakaf dan (e) dukungan regulasi wakaf (Level 3). Strategi prioritas selanjutnya adalah: (d) pengembangan institusi pendidikan wakaf, dan (g) teknologi dan komputerisasi manajemen wakaf (Level 2). Yang terakhir namun tidak kalah penting adalah (f) Update dan validasi terkait data wakaf dan wakaf tunai (Level 1).

$\begin{array}{lr}\text { Level 1: } & \frac{\text { E6 }}{\text { थि }} \\ \text { Level 2: } & \frac{\mathrm{E4}, \mathrm{E7}}{\text { थि }} \\ \text { Level 3: } & \text { E1, E2, E3, E5 }\end{array}$

Gambar. 4.2. Level Strategi Pengembangan Wakaf Tunai

Relevan dengan hasil penelitian yang dilakukan oleh Ihsan etal (2017), Hasan \& Siraj (2017) dan Masruki \& Shafii (2013), penelitian ini menunjukkan bahwa kriteria penting dalam strategi pengembangan wakaf tunai di Indonesia adalah faktor transparansi keuangan (akuntabilitas). Hal ini menyiratkan bahwa lembaga wakaf uang harus selalu dapat dipercaya dan bertanggung jawab penuh dalam mengelola dana wakaf. Di sisi ini, konsep akuntabilitas, transparansi dan aksesibilitas menempati kriteria yang sangat penting terkait dengan tanggung jawab lembaga wakaf dalam menyajikan, melaporkan dan mengungkapkan seluruh kegiatan dan sejauh mana laporan keuangan mengandung semua informasi yang relevan yang dibutuhkan oleh wakaf dan kemudahan informasi yang diakses oleh publik.

Dari aspek tantangan yang dihadapi dalam pengembangan wakaf tunai di Indonesia, inti dan masalah dasar adalah (E4) Sistem (Level 4). Tantangan berikutnya 
adalah: (e) Asepk Peraturan, (f) Produk, dan (g) Teknologi informasi (Level 3). Masalah berikutnya adalah: (b) Kepercayaan, dan (c) aspek Syariah (Level 2). Aspek terakhir namun tidak kalah penting adalah (a) Sumber daya manusia (Level 1).

Aspek 'sistem' adalah kunci untuk tantangan pengembangan wakaf tunai di Indonesia. Hal ini relevan dengan hasil penelitian yang dilakukan oleh Hassan et al (2018). Hassan menyatakan bahwa lembaga wakaf yang ideal memiliki sistem manajemen yang lengkap dan profesional. Temuannya mengidentifikasi tiga komponen utama yang sangat penting untuk manajemen wakaf yang efisien, yakni manajemen penelitian, manajemen investasi dan manajemen properti. Keberadaan komponen-komponen ini akan memungkinkan lembaga wakaf untuk mengelola wakaf secara efektif sehingga akan memainkan peran sosial yang efektif dalam mengembangkan umat Islam dan publik secara umum. Temuan ini akan membantu pembuat kebijakan dan manajemen lembaga wakaf untuk menyusun strategi wakaf sebagai pendorong pembangunan sosial dan ekonomi (Hassan et al, 2018).

Untuk aspek pemangku kepentingan atau aktor yang terlibat dan terkait dalam pengembangan wakaf tunai di Indonesia, aktor pentingnya adalah: (c) Pemerintah atau regulator, kemudian (d) Bank Indonesia dan (g) Badan Wakaf Indonesia. Selanjutnya tingkat pemangku kepentingan berikutnya yang terlibat dalam wakaf tunai di Indonesia adalah: (a) Waqif dan masyarakat pada umumnya, (b) Lembaga wakaf (nadzir), (e) LKS PWU (bank syariah) dan (f) DPS-DSN MUI.Seperti kita ketahui, pemerintah selaku regulator memiliki pengaruh yang signifikan dalam pengembangan wakaf tunai secara umum. Dalam kasus ini, regulasi yang disediakan diharapkan mampu memfasilitasi pengembangan wakaf tunai baik dari sisi kelembagaan maupun maupun dari aspek lain, pada masa yang akan datang.

\section{SIMPULAN}

Secara umum, wakaf tunai di Indonesia memiliki potensi yang sangat besar dalam peranannya bagi kemanfaatan dan kemaslahatan masyarakat banyak. Berdasarkan hasil analisis, pengembangan wakaf tunai di Indonesia dengan kerangka metode ISM dapat dibagi ke dalam 3 kriteria: (1) Tantangan yang dihadapi dalam pengembangan wakaf tunai, (2) Strategi atau dasar pijak yang diperlukan dalam kerangka pengembangan wakaf tunai dan (3) Stakeholder atau aktor yang terlibat dalam pengembangan wakaf tunai di Indonesia.

Masalah utama dan tantangan yang dihadapi dalam pengembangan wakaf tunai di Indonesia adalah: Aspek sistem, regulasi dan aturan, produk dan teknologi informasi. Strategi dan dasar pijak utama yang diperlukan dalam kerangka pengembangan wakaf tunai di Indonesia adalah: transparansi dan akuntabilitas lembaga wakaf, peningkatan kualitas nazhir pengelola wakaf tunai, dan strategi pemasaran yang inovatif dari lembaga wakaf. Adapun untuk aspek stakeholder atau aktor yang terlibat dan berkaitan dengan 
pengembangan wakaf tunai di Indonesia, aktor penting antara lain: Pemerintah atau regulator, Badan Wakaf Indonesia dan Bank Indonesia.

Relevan dengan hasil penelitian yang dilakukan oleh Ihsan etal (2017), Hasan \& Siraj (2017) dan Masruki \& Shafii (2013), penelitian ini membuktikan bahwa kriteria penting dalam strategi pengembangan wakaf tunai di Indonesia adalah faktor transparansi keuangan (akuntabilitas). Hal ini menyiratkan bahwa lembaga wakaf uang harus selalu dapat dipercaya dan bertanggung jawab penuh dalam mengelola dana wakaf. Tentu saja dengan tata kelola lembaga yang baik atau dikenal dengan Good Waqf Governance.

\section{DAFTAR PUSTAKA}

Alias, N.A.B., Rozali, E.A., \& Sidek, R.S.M. (2015). The history of waqf fund development at hospital Fatih, Istanbul (1470-1481M). Proceedings of The $6^{\text {th }}$ International Symposium on Islam, Civilization and Science, 29-30 September 2015, UKM Malaysia.

Aziz, M.R.A., Yusof, M.A., Johari, F., Ramli, A., \& Sabri, H. (2014). The Relief of Higher Education Loan Through Islamic Waqf Bank. Asian Social Science, Vol. 10, No. 22, pp. 175-181.

Bolanos, R., Fontela, E., Nenclares, A., \& Pastor, P. (2005). Using interpretive structural modelling in strategic decision-making groups. Management Decision, 43(6), 877895.

Budiman A Achmad. (2011). Akuntabilitas Lembaga Pengelola Wakaf. Jurnal Walisongo.19(1)

Çizakça, M. (1998). Awqaf in History and Its Implications for Modern IslamicEconomies. IslamicEconomic Studies, 6 (1), 1998.

Daud,Dalilal, Rahman, A.Rashidah, Sulaiman Zaludin (2011). Waqf reporting to Fulfill Stakeholder Attribution In Waqf Islamic Councils. BMQR 2 (1)

DEKS Bank Indonesia dan DES-FEB UNAIR. 2016. Wakaf : Pengaturan dan Tata Kelola yang Efektif. Departemen Ekonomi dan Keuangan Syariah Bank Indonesia. Jakarta

Devi, Abrista and Rusydiana, Aam Slamet (2016), Islamic Group Lending Model (GLM) and Financial Inclusion", International Journal of Islamic Business Ethics Vol. 1 No 1, pp. 80-94.

Faisal, M.N., and Al-Esmael, B.A. (2014), Modeling the enablers of organizational commitment, Business Process Management Journal, Vol. 20, No. 1, pp. 25-46.

Faisal, M.N. (2015), A study of inhibitors to transparency in red meat supply chains in Gulf cooperation council (GCC) countries, Business Process Management Journal, Vol. 21, No. 6, pp. 1299-1318.

Furqon Ahmad. (2011). “Analisis Praktek Perwakafan Uang pada Lembaga Keuangan Syariah". Jurnal Walisongo. 19(1) 
Godet, M. (1986), "Introduction to 'la prospective': seven key ideas and one scenario method", Futures, Vol. 18, No. 2, pp. 134-157.

Gorvett, R., and Liu, N. (2007), Using interpretive structural modeling to identify and quantify interactive risks. Orlando -USA: ASTIN Colloquium.

Harrison, R., Jaumandreu, J., Mairesse, J., and Peters, B. (2014), "Does innovation stimulate employement? A firm level analysis using comparable micro-data from four European countries", International Journal of Industrial Organization, Vol. 35, pp. 29-43.

Harun, F.M., Possumah, B.T., Shafiai, M.H.B.M., and Noor, A.H.M. (2016), "Issues and economic role of waqf in higher education institution: Malaysian experience", Aliqtishad Journal of Islamic Economics, Vol. 8, No. 1, pp. 149-168.

Hasan, R., Siraj, S.A., and Mohamad, M.H.S. (2017), “Antecedents and outcome of waqif's trust in waqf institution", Journal of Economic Cooperation and Development, Vol.38, No.4, pp.155-180.

Hasbullah Hilmi. (2012). Dinamika Pengelolaan Wakaf Uang (Studi Sosio-Legal Perilaku Pengelolaan Wakaf Uang Pasca Pemberlakuan UU No. 41 Tahun 2004 tentang Wakaf) [Disertasi]. Surabaya: Universitas Islam Negeri Surabaya

Hassan, N., Abdul-Rahman, A., and Yazid, Z. (2018), "Developing a new framework of waqf management", International Journal of Academic Research in Business and Social Sciences, Vol.8, No.2, pp.287-305.

Haura A, Baga L M, Tanjung. (2016). "Wakaf Uang pada Koperasi Jasa Keuangan Syariah (pendekatan Analytical Network Process)". Jurnal Al-Muzara'ah.

Ihsan, H., Sulaiman, M., Alwi, N.M., and Adnan, M.A. (2017), "A study of accountability practice in Dompet Dhuafa waqf of Indonesia", JKAU: Islamic Economics, Vol.30, No.2, pp.13-32.

Islahi, A.A, (1996). Provision of Public Goods : Role of the Voluntary Sector (Waqf) in Islamic History, Seminar Proceeding Series No.30. Jeddah : Islamic Research and Training (IRTI)

Jabeen, F., and Faisal, M.N. (2018), "Imperatives for improving entrepreneurial behavior among females in the UAE: An empirical study and structural model", Gender in Management: An International Journal, pp. 1754-2413.

Jabeen, F., and Faisal, M.N., and Katsioloudes, M.I. (2017), "Entrepreneurial mindset and the role of universities as strategic drivers of entrepreneurship evidence from the UAE", Journal of Small Business and Enterprise Development, Vol. 24, No. 1, pp. 136-157.

Kahf, M, Mahamood, S.M, (2011). Essential Readings in Contemporary Waqf Issues. Kuala Lumpur : CERT Publications Sdn.Bhd

Kanungo S dan V.V. Batnagar, 2002. "Beyond Generic Models for Information System Quality : The Use of Interpretative Structural Modelling (ISM)". Journal of System Research and Behavior Science. Vol. 19 (2), P 531:549.

Lee, D. M. (2007). Structured Decision Making with Interpretive Structural Modelling (ISM). Canada: Sorach Inc. 
Li, M., and Yang, J. (2014), "Analysis of interrelationships between critical waste factors in office building retrofit projects using interpretive structural modeling", International Journal of Construction Management, Vol. 14, No. 1, pp. 15-27.

Marimin (2004), Pengambilan Keputusan Kreteria Majemuk. Teknik dan Aplikasi. Gramedia Widiasarana Indonesia. Jakarta.

Masruki, R., and Shafii, Z. (2013), "The development of waqf accounting in enhancing accountability", Middle-East Journal of Scientific Research, Vol.13, pp.1-6

Mas'udi, Maesaroh, dan Satria Utama. (2016). Analisis terhadap Pengembangan Wakaf Tunai (Waqf al-Nuqud) di Indonesia. Laporan Penelitian Unggulan Prodi Ekonomi dan Perbankan Islam Fakultas Agama Islam. Universitas Muhamadiyah. Yogyakarta.

Muhammad, Abu Su'ud, 1997. Risâlahfí Jawâz Waqf an-Nuqûd, tahqiq: Abû al-Asybâl Shaghîr Ahmad Syâghif al-Bâkistânî . Beirut: Dârlbn Hazm.

Nizar Ahmad. (2014). "Faktor-faktor yang Mempengaruhi Persepsi Wakif tentang Wakaf Uang". Jurnal Bisnis dan Manajemen.. 4(1)

Nurfalah, I., Rusydiana, A.S., Laila, N., and Cahyono, E.F. (2018), "Early warning to banking crises in the dual financial system in Indonesia: The markov switching approach", JKAU: Islamic Economics, Vol.31, No.2, pp.133-156.

Otoritas Jasa Keuangan. (2016). "Peran Perbankan Syariah dalam Mengoptimalkan Aset Wakaf Produktif di Indonesia". OJK. Jakarta

Pitchay, A.A., Meera, A.K.M., and Saleem, M.Y. (2014). "Priority of Waqf Development among Malaysian Cash Waqf Donors: An AHP Approach". Journal of Islamic Finance, Vol.3 No.1 p.013-022.

Ravi, V. (2015), "Analysis of interactions among barriers of eco-efficiency in electronics packaging industry", Journal of Cleaner Production, Vol. 101, pp. 16-25.

Robbyantono, JE. (2016). "Optimalisasi Kemanfaatan Asset Wakaf Produktif Nasional". Badan Wakaf Indonesia '3rd Indonesia Islamic Finance Forum'. Jakarta

Rusydiana, Aam Slamet, and Abrista Devi. (2018), "Mengembangkan koperasi syariah di Indonesia: Pendekatan interpretive structural model (ISM)", Jurnal Economica, Vol. 9, No. 1, 2018.

Rusydiana, Aam Slamet, and Abrista Devi, (2018). "Elaborating cash waqf development in Indonesia using analytic network process". International Journal of Islamic Business and Economics, Vol.2 No.1, pp.1-13.

Rusydiana, Aam Slamet, and Abrista Devi, (2017). "Analisis pengelolaan dana wakaf uang di Indonesia: Pendekatan metode analytic network process (ANP)". Al-Awqaf: Jurnal Wakaf dan Ekonomi Islam, Vol.10, No.2, pp.115-133.

Rusydiana, Aam Slamet, and Salman Al Parisi, (2016). "How far has our wakaf been researched?". Etikonomi, Vol.15, No.1, pp.31-42.

Sage, A (1977), Interpretive Structural Modeling: Methodology for Large-Scale Systems, McGraw-Hill, New York, NY, pp. 91-164. 
Shalih. (2007). Peran Wakaf dalam Maqashid Syari'ah. Dissertation at UIN Jakarta, Indonesia. Unpublished.

Suardi Abbas. (2016). "Potensi Harta Wakaf di Indonesia”.Pemaparan Kegiatan SILAKNAS MES 2016 '3rd Indonesia Islamic Finance Forum'. Jakarta

Suhadi, (1995). Pengembangan Tanah Wakaf dalam Rangka Pelaksanaan Undang-Undang pokok Agraria di KabupatenBantul Yogyakarta. Dissertation at Gajah Mada University, Indonesia. Unpublished.

Suwaidi Ahmad. (2011). Wakaf dan Penerapannya di Negara Muslim. Jurnal Ekonomi dan Hukum Islam. 1(2)

Takkar, J., et.al. (2007). "Development of a Balanced Scorecard, An Integrated Approach of Interpretive Sructural Modeling (ISM) and Analytic Network Process (ANP)". International Journal ofProductivity and Performance Management 56 (1): 25-59.

Venkatesh, V.G., Rathi, S., and Patwa, S. (2015), "Analysis on supply chain risks in indian apparel retail chains and proposal of risk prioritization model using interpretive structural modeling", Journal of Retailing and Consumer Services, Vol. 26, pp. 153-167.

Wadjdy, Farid dan Mursyid. (2007). Wakaf dan Kesejahteraan Umat (Filantropi Islam yang hampir terlupakan), Yogyakarta: Pustaka Pelajar.

Warfield, J.N. (1974), "Developing interconnected matrices in structural modeling", IEEE Transactions on System, Man and Cybernetics, Vol. SMC-4 No. 1, pp. 81-87. 